\title{
PERAN KOMITMEN ORGANISASIONAL DALAM MEMEDIASI PENGARUH KEPUASAN KERJA TERHADAP KINERJA KARYAWAN KRISNA OLEH - OLEH
}

\author{
I Ketut Edy Mardyana ${ }^{1}$ \\ I Gede Riana ${ }^{2}$ \\ ${ }^{1,2}$ Fakultas Ekonomi dan Bisnis Universitas Udayana (Unud), Bali, Indonesia \\ email: edymardyana@gmail.com
}

\begin{abstract}
ABSTRAK
Kepuasan kerja serta komitmen organisasional yang tinggi dapat memicu kinerja karyawan yang sangat mempengaruhi tercapainya tujuan perusahaan. Tujuan penelitian ini adalah untuk mengetahui peran mediasi variabel komitmen organisasional terhadap variabel kepuasan kerja dan kinerja karyawan Krisna Oleh - Oleh Khas Bali I. Populasi penelitian ini adalah 55 orang, dengan metode sampel jenuh. Pengumpulan data melalui kuesioner dan wawancara dan dianalisis dengan SEM - PLS. Hasil pengujian mendapatkan kepuasan kerja berpengaruh positif dan signifikan terhadap kinerja karyawan, kepuasan kerja berpengaruh positif dan signifikan terhadap komitmen organisasional, komitmen organisasional berpengaruh negatif dan signifikan terhadap kinerja karyawan, komitmen organisasional berpengaruh positif dan signifikan dalam memediasi pengaruh kepuasan kerja terhadap kinerja karyawan. Perusahaan diharapkan dapat meningkatkan kepuasan kerja karyawan guna meningkatkan komitmen karyawan terhadap perusahaan sehingga kinerja karyawan akan semakin meningkat. Hal tersebut dapat diwujudkan dengan cara memperlakukan karyawan dengan baik, memberikan penghargaan kepada karyawan dengan kinerja yang baik Kata kunci : kepuasan kerja, komitmen organisasional, kinerja karyawan
\end{abstract}

\begin{abstract}
Job satisfaction and organizational commitment can increase employee performance which affects achievement of company goals. The purpose of this study to determine mediating role of organizational commitment on work satisfaction and performance of employees of Krisna by Typical Bali I. The population of this study were 55 people, with a saturated sample method. Data collection through questionnaires and interviews, analyzed by SEM-PLS. The test results shows job satisfaction has significant positive effect on employee performance, job satisfaction has positive significant effect on organizational commitment, organizational commitment has negative significant effect on employee performance, organizational commitment has positive significant effect in mediating the effect of job satisfaction on employee performance. The company is expected to increase employee job satisfaction in order to increase employee commitment to the company so that employee performance will increase. This can be realized by treating employees well, giving awards to employees with good performance

Keywords: job satisfaction, organizational commitment, employee performance
\end{abstract}




\section{PENDAHULUAN}

Bali merupakan ikon pariwisata di Indonesia. Pesona keindahan sumber daya alam, maupun keanekaragaman seni dan budaya serta kekhasan dan keunikan tradisi masyarakat Bali, mampu memberikan daya tarik tersendiri kepada wisatawan baik wisatawan lokal maupun wisatawan mancanegara. Kunjungan wisatawan ke Bali tentu akan terus mengalami perkembangan. Dilihat dari dipercayanya Bali sebagai tempat untuk mengadakan event - event besar. Pada bulan oktober 2018, Bali dipilih dan dipercaya sebagai tuan rumah pertemuan tahunan (IMF-WB), yaitu International Monetery Fund - World Bank yang dihadiri delegasi dari berbagai negara di seluruh dunia. Menurut data statistik dari Badan Pusat Statistik Provinsi Bali diketahui bahwa, perkembangan wisatawan asing yang berkunjung ke Bali 5 tahun terakhir mulai dari tahun 2013 sampai dengan 2017 adalah sebagai berikut.

Tabel 1.

Jumlah Kunjungan Wisatawan Asing Ke Bali Tahun 2013 - 2017

\begin{tabular}{lll}
\hline Tahun & Jumlah Wisatawan Asing (Orang) & Persentase (\%) \\
\hline 2013 & 3.278 .598 & - \\
2014 & 3.766 .638 & 14,89 \\
2015 & 4.001 .835 & 6,27 \\
2016 & 4.927 .937 & 23,14 \\
2017 & 5.697 .739 & 15,62 \\
\hline
\end{tabular}

Sumber : Badan Pusat Statistik Provinsi Bali, 2018

Berdasarkan Tabel 1. diketahui bahwa jumlah kunjungan asing ke Bali dari tahun 2013-2017 terus mengalami perkembangan. Mulai dari tahun 2013 ke 2014 sebanyak 14,89 persen, tahun 2014 ke 2015 sebanyak 6,27 persen, tahun 2015 ke 2016 sebanyak 23,14 persen, dan tahun 2016 ke 2017 sebanyak 15,62 persen. Pertumbuhan jumlah wisatawan di Bali tidak lepas dari semakin gencarnya promosi yang dilakukan pemerintah pusat maupun daerah, terbukti dengan Brand logo yang dimiliki Indonesia yaitu "Wonderful Indonesia” yang sudah familiar terpasang di fasilitas - fasilitas penunjang pariwisata di Indonesia.

Pertumbuhan parwisata yang semakin meningkat tentunya akan merespon tumbuhnya industri kreatif penunjang pariwisata salah satunya bisnis oleh - oleh khas Bali. Dilihat dari perkembangan pariwisata di Bali banyak perusahaan melihat bisnis di bidang oleh - oleh sebagai peluang bisnis.

Pasar oleh - oleh merupakan salah satu tujuan wisatawan saat mengunjungi daerah wisata baik untuk sekedar berjalan - jalan maupun membeli cinderamata. Oleh - oleh tersebut biasanya selalu dikaitkan dengan ciri khas suatu kota atau negara. Misalnya kota Yogyakarta terkenal dengan bakpia, Palembang terkenal akan pempek dan Bali dengan pie susu nya. Perkembangan pasar oleh - oleh menjadi sangat cepat, khususnya pasar oleh - oleh modern. Berbagai kerajinan tangan lokal yang berbentuk unik disajikan sehingga semakin menarik minat pengunjung.

Perusahaan tidak ada artinya tanpa adanya sumber daya manusia, sebab dalam mencapai tujuan dan kesuksesan perusahaan, manusia memiliki peran sentral dalam mengendalikan elemen - elemen yang ada di perusahaan seperti modal, 
teknologi dan uang (Indrawan \& Dewi, 2014). Sumber daya manusia dalam hal ini karyawan berperan besar dalam mendukung pencapaian tujuan perusahaan melalui kinerja yang dikontribusikan dengan penyelesaian tugas - tugas yang dibebankan (Damayanthi \& Sintaasih, 2016)

Suatu perusahaan membutuhkan Sumber daya manusia (SDM) untuk menggerakkan sumber daya lainnya. Keberhasilan suatu organisasi sangat dipengaruhi oleh kualitas SDM, SDM tersebut akan baik kualitas dan kinerjannya bila dipimpin dan dikelola dengan tepat. Untuk dapat mengelola SDM dengan baik, setiap pemimpin dan manajer serta bagian yang menangani SDM harus mengerti masalah manajemen SDM dengan baik pula

Krisna Oleh - Oleh Khas Bali merupakan salah satu pemimpin pasar di bidang oleh - oleh khas Bali. Awalnya Krisna Oleh - Oleh Khas Bali pertama kali didirikan di daerah Denpasar Timur, khususnya di daerah desa adat Sumerta dengan nama Krisna Oleh - Oleh Khas Bali I. Hingga kini Krisna Oleh - Oleh Khas Bali sudah memiliki 8 cabang perusahaan yang bergerak di bidang oleh - oleh yang tersebar di Bali. Masalah utama dalam perusahaan yang dianggap sebagai isu bisnis berkaitan dengan sumber daya manusia serta perlu mendapat perhatian organisasi adalah masalah kinerja karyawan. Banyaknya pesaing pada perusahaan sejenis membuat Krisna Oleh - Oleh Khas Bali I harus meningkatkan kinerja karyawan agar tidak kalah saing.

Era globalisasi menuntut perusahaan - perusahaan untuk dapat lebih bersaing. Perusahaan harus memiliki keunggulan dan daya saing, sehingga mampu bertahan di antara perusahaan - perusahaan lain. Keberhasilan suatu perusahaan sangat dipengaruhi oleh kinerja karyawannya. Fadilah dkk. (2014) menjelaskan bahwa perusahaan membutuhkan karyawan yang mampu bekerja lebih baik dan lebih cepat, sehingga diperlukan karyawan yang mempunyai kinerja ( $J o b$ Performance) yang tinggi. Kinerja karyawan dapat timbul dari berbagai faktor dalam organisasi, diantaranya karena adanya kepuasan kerja dan komitmen organisasional yang tinggi.

Widyastuti (2015) menyatakan, kinerja karyawan merupakan hasil dari prestasi kerja karyawan yang dinilai dari segi kualitas maupun kuantitas berdasarkan standar kerja yang ditentukan oleh pihak organisasi. Kinerja merupakan tolak ukur karyawan dalam melaksanakan tugas yang ditargetkan untuk diselesaikan. Kinerja menjadi gambaran mengenai tingkat pencapaian pelaksanaan suatu kegiatan dalam mewujudkan sasaran, tujuan, visi dan misi organisasi yang tertuang dalam strategi perencanaan suatu organisasi, karenanya kinerja karyawan merupakan hal yang patut mendapat perhatian penting dari pihak perusahaan

Variabel yang dapat mempengaruhi kinerja karyawan adalah kepuasan kerja. Shurbagi (2014) berpendapat bahwa kepuasan kerja merupakan cara pandang seseorang baik yang bersifat positif maupun negatif tentang pekerjaannya. Karyawan yang memiliki kepuasan kerja yang tinggi mengakibatkan karyawan tersebut akan menjadi semakin setia kepada organisasi, termotivasi, merasa senang dalam bekerja, dan pada akhirnya akan tercapai tujuan perusahaan. Sedangkan karyawan yang merasa tidak puas cenderung menghindar dari tugas dan tanggung jawab, sehingga dapat mengganggu proses pencapaian tujuan perusahaan (Indrawan \& Dewi, 2014) 
Kepuasan kerja yang rendah dapat menimbulkan berbagai dampak negatif seperti disiplin kerja merosot, semangat dan gairah kerja menurun, dan sering melakukan kesalahan dalam pekerjaan sehingga berakibat pada produktivitas kerja yang menurun. Penelitian yang dilakukan oleh Talasaz et al. (2014) menyatakan kepuasan kerja berpengaruh signifikan terhadap kinerja karyawan. Hal tersebut menunjukkan bahwa semakin baik kepuasan kerja yang dirasakan oleh karyawan, maka akan diikuti dengan meningkatnya kinerja karyawan.

Hasil penelitian ini bertolak belakang dengan hasil penelitian Than et al. (2016) yang menyatakan bahwa kepuasan kerja karyawan tidak berpengaruh signifikan terhadap kinerja karyawan. peningkatan kepuasan kerja akan mempengaruhi kualitas kerja karyawan, dimana akan memiliki pengaruh yang baik terhadap pencapain tujuan perusahaan. Meningkatkan kepuasan karyawan adalah kunci suksesnya organisasi bisnis, hal tersebut merupakan dasar bagi perusahaan untuk melihat seperti apa keinginan karyawan, lingkungan kerja yang diinginkan dan dengan hal tersebut akan dapat meningkatkan pengabdian karyawan (Rizwan, 2014)

Pihak manajemen harus bisa berupaya meningkatkan kinerja karyawan dengan berbagai cara, salah satunya adalah dengan cara menanamkan komitmen karyawannya terhadap organisasi. Rendahnya komitmen didalam suatu organisasi menunjukan kurangnya tanggung jawab seorang karyawan dalam melaksanakan pekerjaannya.

Komitmen menjadi semakin sulit diterapkan mengingat banyaknya perusahaan yang menggunakan sistem kontrak kepada karyawannya. Komitmen merupakan keterkaitan seorang individu dengan organisasinya, maka cukup sulit mengharapkan komitmen yang kuat dalam kondisi ini.

Ardi \& Sudarma (2015) mengatakan komitmen organisasional mencakup sejauh mana anggota dalam organisasi tersebut menganggap dirinya bagian dari organisasi serta seberapa kuat keinginnya tetap dalam organisasi dan sejauh mana anggota organisasi menerima nilai - nilai dan tujuan yang ada dalam organisasi.

Komitmen Organisasional memiliki pengaruh terhadap kepuasan kerja dan kinerja karyawan. Dengan adanya kepuasan, komitmen organisasional pun akan dapat ditingkatkan. Jika komitmen telah terbentuk dengan baik maka akan berdampak pula kepada kinerja karyawan. Sebaliknya jika komitmen karyawan menurun maka akan menyebabkan penurunan kinerja karyawan dan berdampak kepada citra maupun pendapatan perusahaan.

Komitmen organisasional penting dan wajib dimiliki karyawan, sebab hal tersebut menjadikan karyawan untuk lebih bertanggung jawab terhadap pekerjaan mereka dibandingkan dengan yang tidak memiliki komitmen. Karyawan akan lebih optimal dalam mencurahkan pikiran, tenaga, perhatian serta waktu untuk pekerjaannya agar apa yang dikerjakan sesuai dengan keinginan perusahaan.

Menurut Novita dkk. (2016), Wahyudi \& Sudibya (2016) Komitmen Organisasional berpengaruh positif dalam memediasi kepuasan kerja terhadap kinerja karyawan. Berbeda dengan Penelitian Kusuma \& Lina (2018), Rosita \& Yuniati (2016) serta Triwahyuni \& Ekowati (2017) yang menyebutkan komitmen organisasional tidak mampu memediasi kepuasan kerja terhadap kinerja karyawan. 
Penelitian ini dilakukan di Krisna Oleh - Oleh Khas Bali I. Berdasarkan hasil observasi dan wawancara awal dengan pihak Krisna Oleh - Oleh Khas Bali I, diperoleh informasi adanya permasalahan yang berkaitan dengan kinerja karyawan. Dilihat dari ada beberapa karyawan tidak dapat menyelesaikan tugasnya tepat waktu sesuai dengan target yang telah ditetapkan, beberapa karyawan tidak dapat melakukan fungsi pekerjaannya secara mandiri tanpa intervensi, serta beberapa karyawan masih sering datang terlambat ke kantor.

Berdasarkan hasil wawancara dengan beberapa karyawan Krisna Oleh - Oleh Khas Bali I, ada gejala - gejala permasalahan yang berkaitan dengan kinerja tersebut disebabkan karena kepuasan kerja dan komitmen organisasional karyawan rendah. Indikasi rendahnya kepuasan kerja karyawan dimana beberapa karyawan mengeluh dengan sistem gaji yang dirasa masih kurang dan kadang tidak sesuai dengan pekerjaan yang telah dikerjakan, kurangnya kesempatan promosi, pekerjaan yang monoton, serta adanya karyawan yang bermalas - malasan saat bekerja yang mengindikasikan menurunnya kepuasan kerja karyawan.

Indikasi rendahnya komitmen organisasional pada karyawan Krisna Oleh Oleh Khas Bali I, dimana ada beberapa karyawan yang berwajah cemberut saat melayani pelanggan, berpakaian tidak rapi dan tidak memperdulikan pelanggan yang meminta bantuan. Kurangnya rasa kekeluargaan dalam perusahaan yang menyebabkan beberapa karyawan kurang merasa nyaman untuk tinggal dalam perusahaan ini.

Menurut Abdulwahab (2016) kepuasan kerja berpengaruh positif dan signifikan terhadap kinerja guru pada sekolah menengah di Indonesia, kepuasan kerja memang sangat diperlukan oleh seorang karyawan dalam meningkatkan kinerja masing - masing individu meskipun menurut sifatnya kepuasan kerja itu sendiri sangat relatif atau berbeda antara satu orang dengan orang lainnya. Kepuasan kerja berpengaruh positif dan signifikan terhadap kinerja karyawan, hasil penelitian ini menunjukkan tingginya kepuasan kerja yang diperoleh karyawan, maka akan semakin tinggi kinerja karyawan

Hal ini sesuai dengan penelitian Talasaz et al. (2014), Riyadi (2015), Anwar et al. (2015) yang menyatakan kepuasan kerja berpengaruh signifikan terhadap kinerja karyawan.

Berdasarkan hasil penelitian diatas, hipotesis yang dapat diajukan dalam penelitian ini adalah :

$\mathrm{H}_{1}$ : Kepuasan Kerja berpengaruh positif dan signifikan terhadap kinerja karyawan.

Penelitian yang dilakukan Rehman et al. (2013) mengenai pengaruh kepuasan kerja terhadap komitmen organisasional menunjukan bahwa kepuasan kerja berpengaruh positif terhadap komitmen organisasional. Dwiki \& Riana (2018) menyatakan semakin baik kepuasan kerja karyawan, maka komitmen organisasional karyawan pada PT. Grha Humanindo akan semakin meningkat.. Hal ini sejalan dengan penelitian yang dilakukan oleh Shah et al. (2014), Imam et al. (2014) yang menyatakan bahwa kepuasan kerja berpengaruh positif dan signifikan terhadap komitmen organisasional.

Berdasarkan hasil penelitian diatas, hipotesis yang dapat diajukan dalam penelitian ini adalah : 
$\mathrm{H}_{2}$ : Kepuasan Kerja berpengaruh positif dan signifikan terhadap Komitmen Organisasional.

Penelitian yang dilakukan oleh Ghorbanpour et al. (2014) menunjukkan bahwa komitmen organisasi berpengaruh positif dan signifikan terhadap kinerja karyawan. Menurut Akbar dkk. (2017) terdapat pengaruh positif antara komitmen organisasional terhadap kinerja karyawan PT. Pelindo Suranaya.

Menurut Damaryanti \& Dewi (2016) komitmen organisasional berpengaruh positif dan signifikan terhadap kinerja karyawan FEB Unud, karyawan yang memiliki komitmen organisasional yang tinggi terhadap perusahaannya, akan menunjukkan kinerja yang meningkat. Sejalan dengan penelitian Asiedu et al. (2014) menyatakan komitmen organisasi juga memiliki korelasi positif yang signifikan secara statistik pada kinerja karyawan.

Berdasarkan hasil penelitian diatas, hipotesis yang dapat diajukan dalam penelitian ini adalah :

$\mathrm{H}_{3}$ : Komitmen Organisasional berpengaruh positif dan signifikan terhadap

kinerja karyawan.

Hasil penelitian Novita dkk. (2016) kepuasan kerja dan komitmen organisaisonal ditingkatkan maka kinerja karyawan akan mengalami peningkatan. Komitmen organisasional mampu beroperasi sebagai variabel mediasi dalam hubungan antara kepuasan kerja dan kinerja karyawan. Hal ini memberikan makna bahwa kinerja karyawan semakin baik apabila pengaruh kepuasan kerja semakin baik dengan didahului terciptanya komitmen yang semakin tinggi yang dimiliki oleh individu terhadap organisasinya.

Fauzi dkk. (2016) Terdapat pengaruh positif yang signifikan antara budaya organisasi, kepuasan kerja dan komitmen organisasional secara bersama - sama terhadap kinerja karyawan. Komitmen organisasional mampu memediasi kepuasan kerja terhadap kinerja karyawan, semakin kuat komitmen organisasional maka semakin tinggi kepuasan kerja meningkatkan kinerja karyawan.

Wahyudi \& Sudibya (2016) dalam penelitiannya mengemukakan bahwa kepuasan kerja dan komitmen organisasional berpengaruh positif terhadap kinerja karyawan. Apabila kepuasan kerja dan komitmen organisasional pada Natya Hotel, Kuta Bali meningkat, maka kinerja karyawan juga akan mengalami peningkatan.

Berdasarkan hasil penelitian diatas, hipotesis yang dapat diajukan dalam penelitian ini adalah :

$\mathrm{H}_{4}$ : Komitmen organisasional berpengaruh signifikan dalam memediasi pengaruh kepuasan kerja terhadap kinerja karyawan.

\section{METODE PENELITIAN}

Penelitian ini menggunakan desain penelitian asosiatif. Lokasi pada penelitian ini dilakukan di Krisna Oleh - Oleh Khas Bali I, yang beralamat di Jalan Nusa Indah No. 77, Sumerta, Denpasar Timur, Kota Denpasar-Bali, 80236. Lokasi ini dipilih karena ditemukan masalah yang terkait dengan variabel kepuasan kerja, komitmen organisasional dan kinerja karyawan.Objek dari penelitian ini adalah kepuasan kerja, komitmen organisasional dan kinerja karyawan. 
Variabel bebas dalam penelitian ini adalah Kepuasan Kerja (X). Variabel terikat dalam penelitian ini adalah Kinerja Karyawan (Y). Variabel dalam penelitian ini adalah Komitmen Organisasional (M).

Kinerja karyawan merupakan hasil kerja yang dicapai oleh individu dari tugas dan pekerjaan yang diberikan sesuai dengan standar prilaku yang ditetapkan perusahaan Koopmans et al. (2014). Indikator - indikator untuk mengukur kinerja karyawan, yaitu: Kinerja tugas (Task performance) dan Kinerja kontekstual (Contextual performance)

Kepuasan kerja merupakan tingkat kepuasan yang dirasakan karyawan terkait dengan pekerjaannya (Puangyoykeaw \& Nishide, 2015). Indikator - indikator pengukuran tingkat kepuasan kerja yang dipakai dalam penelitian ini mengacu pada penelitian Andini dkk. (2018) yaitu: Pekerjaan itu sendiri, Gaji, Promosi jabatan, Supervisi dan Rekan kerja

Komitmen organisasional merupakan keadaan psikologis seorang karyawan yang dapat dilihat dari rasa loyalitas karyawan serta mampu fokus terhadap tujuan yang telah ditetapkan oleh organisasi. Indikator - indikator pengukuran tingkat komitmen organisasional yaitu: Affective Commitment, Continuance Commitment, Normative Commitment

Data kualitatif dalam penelitian ini berupa pendapat dari responden yang meliputi variabel penempatan, kepuasan kerja, komitmen organisasional, kinerja karyawan, sejarah perusahaan, dan beberapa pernyataan yang terlampir pada kuesioner Data kuantitatif dalam penelitian ini adalah jumlah karyawan di Krisna Oleh - Oleh Khas Bali I Populasi pada penelitian ini adalah karyawan Krisna Oleh - Oleh Khas Bali I yang berjumlah 55 orang

Teknik penentuan sampel yang digunakan dalam penelitian ini adalah teknik sampling jenuh karena keseluruhan anggota populasi memungkinkan untuk dijadikan sampel. Jadi, sampel dalam penelitian ini berjumlah 55 orang. Metode pengumpulan data yang digunakan dalam penelitian ini untuk mempermudah memperoleh data yaitu: Observasi, Wawancara, Kuesioner

\section{HASIL DAN PEMBAHASAN}

Penelitian ini menggunakan sampel jenuh, dimana seluruh populasi menjadi sampel yaitu 55 orang karyawan. Berikut data responden berdasarkan jenis kelamin, usia, tingkat pendidikan, jabatan dan masa kerja. Karakteristik responden disajikan pada Tabel 2 .

Karyawan berjenis kelamin perempuan lebih mendominasi dibandingkan laki - laki, hal ini dikarenakan pada saat perekrutan karyawan, karyawan perempuan lebih dibutuhkan pada bidangnya. Pada Tabel dapat dilihat pula sebagian besar karyawan dengan pekerjaan SPG, hal ini dikarenakan pada bagian tersebut paling diperlukan.

Karyawan dengan lama kerja lebih dari 5 Tahun yang paling banyak diantara yang lainnya, hal ini dikarenakan instansi mempertahankan karyawan lama dengan pengalaman bekerja lebih lama dan jarang melakukan perekrutan karyawan baru.

Karyawan dengan jenjang SMA/SMK yang paling banyak diantara yang lainnya, hal ini dikarenakan pada saat perekrutan tamatan minimal SMA/SMK yang 
dicari. Karyawan dengan usia 20 - 30 Tahun yang paling banyak diantara yang lainnya, hal ini dikarenakan termasuk usia produktif bekerja dan paling dibutuhkan.

Tabel 2.

Daftar Karakteristik Responden

\begin{tabular}{|c|c|c|c|c|}
\hline No. & Karakteristik Responden & Pilihan & $\begin{array}{l}\text { Jumlah } \\
\text { (Orang) }\end{array}$ & $\begin{array}{c}\text { Persentase } \\
(\%)\end{array}$ \\
\hline \multirow[t]{3}{*}{1} & Jenis Kelamin & Laki-laki & 15 & 27,3 \\
\hline & & Perempuan & 40 & 72,7 \\
\hline & Jumlah & & 55 & 100 \\
\hline \multirow[t]{4}{*}{2} & Usia & $>20$ Tahun & 2 & 3,6 \\
\hline & & $20-30$ Tahun & 41 & 74,5 \\
\hline & & $>30$ Tahun & 12 & 21,8 \\
\hline & Jumlah & & 55 & 100 \\
\hline \multirow[t]{5}{*}{3} & Tingkat Pendidikan & SMP & 7 & 12,7 \\
\hline & & SMA/SMK & 45 & 81,8 \\
\hline & & Diploma & 1 & 1,8 \\
\hline & & S1 & 2 & 3,6 \\
\hline & Jumlah & & 55 & 100 \\
\hline \multirow[t]{11}{*}{4} & Jabatan & Kepala Toko & 1 & 1,8 \\
\hline & & Wakil Kepala Toko & 1 & 1,8 \\
\hline & & Keuangan & 1 & 1,8 \\
\hline & & Komisi & 1 & 1,8 \\
\hline & & Accounting & 1 & 1,8 \\
\hline & & Kasir & 10 & 18,2 \\
\hline & & Stiker & 3 & 5,5 \\
\hline & & SPG & 25 & 45,5 \\
\hline & & SPB & 4 & 7,3 \\
\hline & & Security & 8 & 14,5 \\
\hline & Jumlah & & 55 & 100 \\
\hline \multirow[t]{4}{*}{5} & Masa Kerja & $<1$ Tahun & 4 & 7,3 \\
\hline & & 1-5 Tahun & 21 & 38,2 \\
\hline & & $>5$ Tahun & 30 & 54,5 \\
\hline & Jumlah & & 55 & 100 \\
\hline
\end{tabular}

Sumber : Data Primer Diolah, 2019

Hasil uji validitas pada Tabel 3. menunjukkan bahwa seluruh instrumen penelitian yang digunakan untuk mengukur variabel Kepuasan kerja, Komitmen Organisasional, dan Kinerja Karyawan memiliki nilai koefisien korelasi dengan skor total seluruh item pernyataan lebih besar dari 0,30.

Hal ini menunjukkan bahwa butir - butir pernyataan dalam instrumen penelitian tersebut valid dan layak digunakan sebagai instrumen penelitian.

Hasil uji reliabilitas yang disajikan dalam Tabel 4. menunjukkan bahwa seluruh instrumen penelitian memiliki koefisien Cronbach's Alpha lebih dari 0,60. Jadi dapat dinyatakan bahwa seluruh variabel telah memenuhi syarat reliabilitas atau kehandalan sehingga dapat digunakan untuk melakukan penelitian. 
Tabel 3.

Rekapitulasi Hasil Uji Validitas Instrumen Penelitian

\begin{tabular}{|c|c|c|c|c|}
\hline Variabel & Indikator & $\begin{array}{c}\text { Koefisien } \\
\text { Korelasi } \\
\end{array}$ & $\begin{array}{c}\text { Korelasi } \\
\text { Batas }\end{array}$ & Keterangan \\
\hline \multirow{10}{*}{ Kepuasan kerja (X) } & $X_{.1}$ & 0,756 & 0,30 & Valid \\
\hline & $\mathrm{X}_{.2}$ & 0,837 & 0,30 & Valid \\
\hline & $\mathrm{X}_{3}$ & 0,731 & 0,30 & Valid \\
\hline & $\mathrm{X}_{.4}$ & 0,812 & 0,30 & Valid \\
\hline & $\mathrm{X}_{.5}$ & 0,755 & 0,30 & Valid \\
\hline & $\mathrm{X}_{.6}$ & 0,841 & 0,30 & Valid \\
\hline & $X_{.7}$ & 0,682 & 0,30 & Valid \\
\hline & $\mathrm{X}_{.8}$ & 0,820 & 0,30 & Valid \\
\hline & $\mathrm{X}_{9}$ & 0,827 & 0,30 & Valid \\
\hline & $X_{.10}$ & 0,775 & 0,30 & Valid \\
\hline \multirow{7}{*}{$\begin{array}{c}\text { Komitmen } \\
\text { Organisasional (M) }\end{array}$} & $\mathrm{M}_{.1}$ & 0,780 & 0,30 & Valid \\
\hline & $\mathrm{M}_{.2}$ & 0,887 & 0,30 & Valid \\
\hline & $\mathrm{M}_{.3}$ & 0,718 & 0,30 & Valid \\
\hline & $\mathrm{M}_{4}$ & 0,823 & 0,30 & Valid \\
\hline & $\mathrm{M}_{.5}$ & 0,837 & 0,30 & Valid \\
\hline & $M_{6} 6$ & 0,874 & 0,30 & Valid \\
\hline & $\mathrm{M}_{.7}$ & 0,854 & 0,30 & Valid \\
\hline \multirow{8}{*}{ Kinerja Karyawan (Y) } & $Y_{.1}$ & 0,779 & 0,30 & Valid \\
\hline & $\mathrm{Y}_{.2}$ & 0,792 & 0,30 & Valid \\
\hline & $\mathrm{Y}_{.3}$ & 0,819 & 0,30 & Valid \\
\hline & $Y_{.4}$ & 0,806 & 0,30 & Valid \\
\hline & $\mathrm{Y}_{.5}$ & 0,822 & 0,30 & Valid \\
\hline & $Y_{.6}$ & 0,845 & 0,30 & Valid \\
\hline & $\mathrm{Y}_{.7}$ & 0,872 & 0,30 & Valid \\
\hline & $\mathrm{Y}_{.8}$ & 0,837 & 0,30 & Valid \\
\hline
\end{tabular}

Sumber : Data Primer Diolah, 2019

Tabel 4.

Rekapitulasi Hasil Uji Reliabilitas Instrumen Penelitian

\begin{tabular}{clcc}
\hline No. & \multicolumn{1}{c}{ Variabel } & Cronbach's Alpha & Keterangan \\
\hline $\mathbf{1}$ & Kepuasan kerja (X) & 0,926 & Reliabel \\
$\mathbf{2}$ & Komitmen Organisasional (M) & 0,918 & Reliabel \\
$\mathbf{3}$ & Kinerja Karyawan (Y) & 0,928 & Reliabel \\
\hline Sumber $:$ Data Primer Diolah, 2019 & &
\end{tabular}

Tabel 5. menunjukan kepuasan kerja secara keseluruhan baik hal ini dapat dilihat dari keseluruhan rata - rata nilai kepuasan kerja yaitu 3,64. Nilai rata - rata tertinggi pada pernyataan "Saya dan rekan kerja mampu bekerjasama dalam menyelesaikan pekerjaan". 
Hal ini menunjukan karyawan memiliki kemampuan bekerjasama dengan baik. Karyawan memiliki hubungan yang baik sesama rekan kerja, dan juga karyawan merasa puas karena diberikan kesempatan untuk mengembangkan diri.

Nilai rata - rata terendah terdapat pada pernyataan "Saya merasa puas dengan tunjangan yang diberikan perusahaan". Hal ini menunjukan bahwa perusahaan belum mampu memberikan kepuasan kepada karyawan dalam memberikan tunjangan.

Tabel 5.

Deskripsi Jawaban Responden Terhadap Kepuasan kerja

\begin{tabular}{|c|c|c|c|c|c|c|c|c|}
\hline \multirow[b]{2}{*}{ No } & \multirow[b]{2}{*}{ Daftar Pernyataan } & \multicolumn{5}{|c|}{ Pilihan Jawaban } & \multirow{2}{*}{$\begin{array}{l}\text { Rata } \\
- \\
\text { rata }\end{array}$} & \multirow[b]{2}{*}{ Kategori } \\
\hline & & STS & TS & $\mathrm{CS}$ & $\mathbf{S}$ & SS & & \\
\hline & Pekerjaan itu sendiri & & & & & & & \\
\hline 1 & $\begin{array}{l}\text { Saya merasa puas karena } \\
\text { mendapatkan kesempatan untuk } \\
\text { belajar atas pekerjaan yang } \\
\text { diberikan }\end{array}$ & 0 & 2 & 18 & 29 & 6 & 3,71 & Puas \\
\hline 2 & $\begin{array}{l}\text { Saya merasa puas karena saya } \\
\text { dapat menguasai pekerjaan yang } \\
\text { diberikan } \\
\text { Gaji }\end{array}$ & 0 & 2 & 19 & 30 & 4 & 3,65 & Puas \\
\hline 3 & $\begin{array}{l}\text { Saya merasa puas karena gaji yang } \\
\text { saya terima sesuai dengan beban } \\
\text { kerja yang diberikan }\end{array}$ & 0 & 10 & 19 & 20 & 6 & 3,40 & $\begin{array}{l}\text { Cukup } \\
\text { Puas }\end{array}$ \\
\hline 4 & $\begin{array}{l}\text { Saya merasa puas } \\
\text { tunjangan yang dengan } \\
\text { perusahaan } \\
\text { Promosi }\end{array}$ & 0 & 10 & 19 & 22 & 4 & 3.36 & $\begin{array}{l}\text { Cukup } \\
\text { Puas }\end{array}$ \\
\hline 5 & $\begin{array}{l}\text { Saya memperoleh kesempatan } \\
\text { untuk naik jabatan }\end{array}$ & 0 & 7 & 19 & 23 & 6 & 3,51 & Puas \\
\hline 6 & $\begin{array}{l}\text { Saya merasa puas dengan } \\
\text { kersempatan yang diberikan untuk } \\
\text { mengembangkan diri } \\
\text { Supervisi }\end{array}$ & 0 & 1 & 20 & 25 & 9 & 3,76 & Puas \\
\hline 7 & $\begin{array}{l}\text { Atasan selalu mengontrol } \\
\text { pekerjaan yang saya lakukan }\end{array}$ & 0 & 3 & 22 & 24 & 6 & 3,60 & Puas \\
\hline 8 & $\begin{array}{l}\text { Atasan memberikan dukungan } \\
\text { kepada saya } \\
\text { Rekan Kerja }\end{array}$ & 0 & 2 & 24 & 24 & 5 & 3,58 & Puas \\
\hline 9 & $\begin{array}{l}\text { Saya memiliki hubungan yang } \\
\text { baik dengan rekan kerja }\end{array}$ & 0 & 0 & 22 & 20 & 13 & 3,84 & Puas \\
\hline 10 & $\begin{array}{l}\text { Saya dan rekan kerja mampu } \\
\text { bekerjasama dalam } \\
\text { menyelesaikan pekerjaan }\end{array}$ & 0 & 0 & 18 & 20 & 17 & 3,98 & Puas \\
\hline & Rata - rata kese & Iruhar & & & & & 3,64 & Puas \\
\hline
\end{tabular}

Variabel Komitmen Organisasional dalam penelitian ini merupakan variabel mediasi yang diukur dengan menggunakan 3 pernyataan yang berhubungan dengan komitmen organisasional dari perusahaan. 
Secara rinci hasil penelitian mengenai jawaban responden terhadap variabel komitmen organisasional dapat dilihat pada Tabel 6 berikut.

Tabel 6.

Deskripsi Jawaban Responden Terhadap Komitmen Organisasional

\begin{tabular}{|c|c|c|c|c|c|c|c|c|}
\hline \multirow{2}{*}{ No } & \multirow{2}{*}{ Daftar Pernyataan } & \multicolumn{5}{|c|}{ Pilihan Jawaban } & \multirow{2}{*}{$\begin{array}{l}\text { Rata - } \\
\text { rata }\end{array}$} & \multirow{2}{*}{ kategori } \\
\hline & & STS & TS & $\mathbf{C S}$ & $\mathbf{S}$ & SS & & \\
\hline & Komitmen Afektif & & & & & & & \\
\hline 1 & $\begin{array}{l}\text { Saya merasa terikat secara } \\
\text { emosional dengan perusahaan ini }\end{array}$ & 0 & 0 & 12 & 17 & 26 & 4,25 & $\begin{array}{l}\text { Sangat } \\
\text { Tinggi }\end{array}$ \\
\hline 2 & $\begin{array}{l}\text { Saya merasa bangga menjadi } \\
\text { bagian dari perusahaan ini }\end{array}$ & 0 & 7 & 14 & 26 & 8 & 3,64 & Tinggi \\
\hline 3 & $\begin{array}{l}\text { Saya bangga terhadap perusahaan } \\
\text { tempat saya bekerja. }\end{array}$ & 0 & 1 & 16 & 22 & 16 & 3,96 & Tinggi \\
\hline & Komitmen Berkelanjutan & & & & & & & \\
\hline 4 & $\begin{array}{l}\text { Saya merasa rugi apabila keluar } \\
\text { dari perusahaan ini, }\end{array}$ & 0 & 10 & 21 & 18 & 6 & 3,36 & $\begin{array}{l}\text { Cukup } \\
\text { Tinggi }\end{array}$ \\
\hline 5 & $\begin{array}{l}\text { Saya menganggap bekerja pada } \\
\text { perusahaan ini merupakan suatu } \\
\text { kebutuhan. }\end{array}$ & 0 & 1 & 13 & 33 & 8 & 3,87 & Tinggi \\
\hline 6 & $\begin{array}{l}\text { Komitmen Normatif } \\
\text { Saya akan tetap tinggal di } \\
\text { perusahaan karena komitmen saya } \\
\text { terhadap perusahaan }\end{array}$ & 0 & 3 & 20 & 24 & 8 & 3,67 & Tinggi \\
\hline 7 & $\begin{array}{l}\text { Saya akan tetap loyal terhadap } \\
\text { perusahaan }\end{array}$ & 0 & 2 & 17 & 26 & 10 & 3,80 & Tinggi \\
\hline \multicolumn{7}{|c|}{ Rata - rata keseluruhan } & 3,79 & Tinggi \\
\hline
\end{tabular}

Komitmen organisasional secara keseluruhan baik hal ini dapat dilihat dari keseluruhan rata - rata nilai komitmen organisasional yaitu 3,79. Nilai rata - rata tertinggi pada pernyataan "Saya merasa terikat secara emosional dengan perusahaan ini".

Hal ini menunjukan bahwa karyawan memiliki rasa keterikatan terhadap tempat ia bekerja. Karyawan bangga terhadap perusahaan dan menganggap bekerja pada perusahaan tersebut adalah sebuah kebutuhan.

Nilai rata - rata terendah terdapat pada pernyataan "Saya merasa rugi apabila keluar dari perusahaan ini". Hal ini menunjukan bahwa karyawan akan mengalami kerugian jika memutuskan untuk keluar atau resign dari tempat bekerja.

Variabel kinerja karyawan dalam penelitian ini merupakan variabel terikat yang diukur dengan menggunakan 3 pernyataan yang berhubungan dengan kinerja dari karyawan. Secara rinci hasil penelitian mengenai jawaban responden terhadap variabel Kinerja Karyawan dapat dilihat pada Tabel 7.

Tabel 7. menunjukan Kinerja Karyawan secara keseluruhan baik hal ini dapat dilihat dari keseluruhan rata - rata nilai Kinerja Karyawan yaitu 3,70. Nilai rata rata tertinggi pada pernyataan "Saya menargetkan hasil yang harus dicapai dalam pekerjaan". 
Hal ini menunjukan karyawan sudah memiliki standar kerja pada dirinya. Karyawan memiliki solusi kreatif dalam menyelesaikan masalah baru dan jika ada karyawan akan mengambil pekerjaan menantang.

Nilai rata - rata terendah terdapat pada pernyataan "Rencana kerja saya berjalan optimal". Hal ini menunjukan bahwa rencana yang dimiliki karyawan tidak sepenuhnya terlaksana dengan baik.

Tabel 7.

Deskripsi Jawaban Responden Terhadap Kinerja Karyawan

\begin{tabular}{|c|c|c|c|c|c|c|c|c|}
\hline \multirow{2}{*}{ No } & \multirow{2}{*}{ Daftar Pernyataan } & \multicolumn{5}{|c|}{ Pilihan Jawaban } & \multirow{2}{*}{$\begin{array}{c}\text { Rata - } \\
\text { rata }\end{array}$} & \multirow{2}{*}{ Kategori } \\
\hline & & STS & TS & CS & $\mathbf{S}$ & SS & & \\
\hline & Kinerja Tugas & & & & & & & \\
\hline 1 & $\begin{array}{l}\text { Saya mengatur rencana kerja } \\
\text { selesai tepat waktu }\end{array}$ & 0 & 1 & 19 & 28 & 7 & 3,75 & Baik \\
\hline 2 & $\begin{array}{l}\text { Rencana kerja saya berjalan } \\
\text { optimal }\end{array}$ & 0 & 7 & 26 & 15 & 7 & 3,40 & $\begin{array}{l}\text { Cukup } \\
\text { baik }\end{array}$ \\
\hline 3 & $\begin{array}{l}\text { Saya menargetkan hasil yang } \\
\text { harus dicapai dalam pekerjaan }\end{array}$ & 0 & 1 & 14 & 25 & 15 & 3,98 & Baik \\
\hline 4 & $\begin{array}{l}\text { Saya mampu memisahkan isu } \\
\text { utama dari isu sampingan di } \\
\text { kantor }\end{array}$ & 0 & 1 & 18 & 30 & 6 & 3,75 & Baik \\
\hline 5 & $\begin{array}{l}\text { Kinerja Kontekstual } \\
\text { Saya mengambil tanggung } \\
\text { jawab lebih (ekstra) }\end{array}$ & 0 & 6 & 24 & 20 & 5 & 3,44 & Baik \\
\hline 6 & $\begin{array}{l}\text { Saya memulai tugas } \\
\text { (pekerjaan) baru, ketika tugas } \\
\text { lama selesai }\end{array}$ & 0 & 1 & 23 & 25 & 6 & 3,65 & Baik \\
\hline 7 & $\begin{array}{l}\text { Jika ada, saya mengambil } \\
\text { pekerjaan menantang }\end{array}$ & 0 & 1 & 17 & 29 & 8 & 3,80 & Baik \\
\hline 8 & $\begin{array}{l}\text { Saya memiliki solusi kreatif } \\
\text { menghadapi masalah baru }\end{array}$ & 0 & 1 & 17 & 28 & 9 & 3,82 & Baik \\
\hline \multicolumn{7}{|c|}{ Rata - rata keseluruhan } & 3,70 & Baik \\
\hline
\end{tabular}

Sumber : Data Primer Diolah, 2019

Dalam penelitian ini, statistik inferensial yang digunakan adalah SEM berbasis varian atau PLS. PLS adalah analisis persamaan structural (SEM) berbasis varian, secara simultan dalam melakukan pengujian model pengukuran dan pengujian model structural.

Outer model yaitu spesifikasi hubungan antara variabel laten dengan indikatornya, atau disebut juga dengan outer relation atau measurement model, mendefinisikan karakteristik konstruk dengan variabel manifesnya.

Berdasarkan Tabel 8. dapat dilihat bahwa semua nilai pada uji validitas convergent lebih besar dari 0,7 . Dengan demikian dapat dinyatakan bahwa data dalam penelitian valid.

Apabila nilai croos loading setiap indikator dari variabel yang bersangkutan lebih besar dibandingkan dengan cross loading variabel lain, maka indikator tersebut dikatakan valid. Nilai validitas diskriminan lebih besar dari pada 0,5 maka variabel laten tersebut sudah menjadi pembanding yang baik untuk model. 
Berdasarkan Tabel 9. dapat dilihat bahwa semua nilai cross loading setiap indikator pada masing - masing variabel lebih besar dari 0,5 Dengan demikian dapat dinyatakan bahwa data dalam penelitian valid.

Tabel 8.

Hasil Uji Validitas Convergent Validity

\begin{tabular}{|c|c|c|c|}
\hline & Kepuasan Kerja (X) & $\begin{array}{l}\text { Kinerja Karyawan } \\
\text { (Y) }\end{array}$ & $\begin{array}{l}\text { Komitmen Organisasional } \\
\text { (M) }\end{array}$ \\
\hline M.1 & & & 0.770 \\
\hline M.2 & & & 0.804 \\
\hline M.3 & & & 0.757 \\
\hline M.4 & & & 0.835 \\
\hline M.5 & & & 0.787 \\
\hline M.6 & & & 0.835 \\
\hline M.7 & & & 0.830 \\
\hline X.1 & 0.830 & & \\
\hline X.10 & 0.833 & & \\
\hline X.2 & 0.841 & & \\
\hline X.3 & 0.775 & & \\
\hline X.4 & 0.880 & & \\
\hline X.5 & 0.828 & & \\
\hline X.6 & 0.809 & & \\
\hline X.7 & 0.796 & & \\
\hline X.8 & 0.845 & & \\
\hline X.9 & 0.841 & & \\
\hline Y.1 & & 0.836 & \\
\hline Y.2 & & 0.804 & \\
\hline Y.3 & & 0.808 & \\
\hline Y.4 & & 0.840 & \\
\hline Y.5 & & 0.758 & \\
\hline Y.6 & & 0.844 & \\
\hline Y.7 & & 0.904 & \\
\hline Y.8 & & 0.845 & \\
\hline
\end{tabular}

Model lain untuk menilai discriminate validity adalah membandingkan akar kuadrat dari average variance extracted (AVE) untuk setiap variabel dengan korelasi antar variabel dengan variabel lainnya didalam model. Model memiliki discrimint yang baik apabila kuadrat AVE untuk setiap variabel lebih besar daripada korelasi antar variabel dan variabel lain dalam satu model atau direkomendasikan nilai pengukuran AVE lebih besar dari 0,5.

Berdasarkan Tabel 10. di atas dapat dilihat bahwa semua nilai AVE validitas confergent lebih besar dari 0,5 . Dengan demikian dapat dinyatakan bahwa data dalam penelitian valid. 
Disamping uji validitas, juga dilakukan uji relabilitas variabel yang diukur dengan dua kriteria yaitu composite reliability dan cronbachs alpha dari blok indikator yang mengukur variabel. Variabel dinyatakan reliable jika nilai composite reliability dan cronbachs alpha diatas 0,70 .

Tabel 9.

Hasil Uji Validitas Discriminant Cross Loading

\begin{tabular}{crrr}
\hline & Kepuasan Kerja (X) & Kinerja Karyawan $(\mathbf{Y})$ & Komitmen Organisasional (M) \\
\hline M.1 & 0.663 & 0.621 & 0.770 \\
M.2 & 0.700 & 0.656 & 0.804 \\
M.3 & 0.529 & 0.603 & 0.757 \\
M.4 & 0.710 & 0.835 \\
M.5 & 0.608 & 0.576 & 0.787 \\
M.6 & 0.545 & 0.610 & 0.835 \\
M.7 & 0.741 & 0.641 & 0.830 \\
X.1 & 0.710 & 0.756 & 0.648 \\
X.10 & 0.830 & 0.621 & 0.624 \\
X.2 & 0.833 & 0.700 & 0.690 \\
X.3 & 0.841 & 0.618 & 0.716 \\
X.4 & 0.775 & 0.750 & 0.724 \\
X.5 & 0.880 & 0.736 & 0.677 \\
X.6 & 0.828 & 0.589 & 0.736 \\
X.7 & 0.809 & 0.587 & 0.602 \\
X.8 & 0.796 & 0.639 & 0.609 \\
X.9 & 0.845 & 0.555 & 0.618 \\
Y.1 & 0.841 & 0.836 & 0.668 \\
Y.2 & 0.704 & 0.804 & 0.611 \\
Y.3 & 0.620 & 0.808 & 0.603 \\
Y.4 & 0.642 & 0.840 & 0.672 \\
Y.5 & 0.739 & 0.758 & 0.706 \\
Y.6 & 0.579 & 0.844 & 0.580 \\
Y.7 & 0.700 & 0.904 & 0.698 \\
Y.8 & 0.650 & 0.845 & 0.682 \\
\hline Sumber : Data Primer Diolah, 2019 & &
\end{tabular}

Tabel 10.

Hasil Uji Validitas Convergent AVE

\begin{tabular}{lc}
\hline & Average Variance Extracted (AVE) \\
\hline Kepuasan Kerja (X) & 0.686 \\
Kinerja Karyawan (Y) & 0.690 \\
Komitmen Organisasional (M) & 0.645 \\
\hline Sumber : Data Primer Diolah, 2019 &
\end{tabular}


Tabel 11.

Hasil Uji Reliabilitas Cronbach's alpha

\begin{tabular}{lc}
\hline & Cronbach's Alpha \\
\hline Kepuasan Kerja (X) & 0.949 \\
Kinerja Karyawan (Y) & 0.935 \\
Komitmen Organisasional (M) & 0.908 \\
\hline Sumber : Data Primer Diolah, 2019 &
\end{tabular}

Berdasarkan Tabel 11. di atas dapat dilihat bahwa semua nilai Cronbach's alpha pada masing - masing variabel lebih besar dari 0,70. Dengan demikian dapat dinyatakan bahwa data dalam penelitian reliabel.

Tabel 12.

Hasil Uji Reliabilitas Composite reliability

\begin{tabular}{ll}
\hline \multicolumn{2}{c}{ Composite Reliability } \\
\hline Kepuasan Kerja (X) & 0.956 \\
Kinerja Karyawan (Y) & 0.947 \\
Komitmen Organisasional (M) & 0.927 \\
\hline Sumber : Data Primer (Diolah), 2019 &
\end{tabular}

Berdasarkan Tabel 12. dapat dilihat bahwa semua nilai Composite reliability pada masing - masing variabel lebih besar dari 0,7. Dengan demikian dapat dinyatakan bahwa data dalam penelitian reliabel.

Tabel 13. Hasil Uji R-square

\begin{tabular}{lcc}
\hline & R Square \\
\hline Kinerja Karyawan (Y) & 0.694 \\
Komitmen Organisasional (M) & 0.648 \\
\hline Sumber : Data Primer Diolah, 2019 &
\end{tabular}

Berdasarkan Taberl 13. diperoleh nilai R-square untuk variabel Kepuasan kerja dan Komitmen Organisasional terhadap Kinerja karyawan sebesar 0,694 yang menunjukkan memiliki besar pengaruh $0,694 \times 100 \%=69,4 \%$. Nilai R-square untuk variabel Kepuasan kerja terhadap Komitmen Organisasional sebesar 0,648 yang menunjukkan memiliki besar pengaruh $0,648 \times 100 \%=64,8 \%$.

Nilai $Q$-square sebesar 0,699 lebih dari 0, sehingga dapat disimpulkan bahwa model mempunyai nilai predictive relvance atau model layak dikatakan memiliki nilai prediktif yang relevan.

Pengujian hipotesis dilakukan dengan perbandingan nilai t-tabel dengan tstatistik dan $\mathrm{p}$ value dengan tingkat signifikan 5 persen. Jika t-statistik lebih tinggi dibandingkan nilai t-table, berarti hipotesis terdukung atau diterima. Hasil perhitungan secara langsung dapat dilihat path coefficient dan total effect. dan derajat kebebasan $\mathrm{N}-\mathrm{k}=55-3=52$, sehingga nilai t tabel yakni 2,006, maka dapat disimpulkan hasil tersebut signifikan, dan sebaliknya apabila nilai t-statistik $<2,006$ maka hasil penelitian tersebut tidak signifikan. 
Nilai $p$-value variabel kepuasan kerja terhadap kinerja karyawan sebesar 0,000 yang dibandingkan dengan signifikan sebesar 0,05 . Karena nilai $p$-value $<$ signifikan $(0,000<0,05)$ dengan nilai beta sebesar positif 0,462 dan nilai t statistics sebesar 3,579 yang dibandingkan dengan t-tabel sebesar 2,006. Karena nilai tstatistics $>$ t-value $(3,579>2,006)$ maka dapat disimpulkan bahwa kepuasan kerja berpengaruh positif signifikan terhadap kinerja karyawan.

Nilai $p$-value variabel kepuasan kerja terhadap komitmen organisasional sebesar 0,000 yang dibandingkan dengan signifikan sebesar 0,05 . Karena nilai $p$ value $<$ signifikan $(0,000<0,05)$ dengan nilai beta sebesar positif 0,805 dan nilai $\mathrm{t}$ statistics sebesar 12,749 yang dibandingkan dengan t-tabel sebesar 2,006. Karena nilai t-statistics $>$ t-value $(12,749>2,006)$ maka dapat disimpulkan bahwa kepuasan kerja berpengaruh positif signifikan terhadap komitmen organisasional.

Nilai $p$-value variabel Komitmen Organisasional terhadap Kinerja Karyawan sebesar 0,008 yang dibandingkan dengan signifikan sebesar 0,05 . Karena nilai $p$ value $<$ signifikan $(0,008<0,05)$ dengan nilai beta sebesar positif 0,415 dan nilai $t$ statistics sebesar 2,675 yang dibandingkan dengan t-tabel sebesar 2,006. Karena nilai t-statistics $>$ t-value $(2,675>2,006)$ maka dapat disimpulkan bahwa komitmen organisasional berpengaruh positif signifikan terhadap kinerja karyawan.

Nilai p-value variabel Kepuasan kerja terhadap Kinerja karyawan melalui komitmen organisasional sebesar 0,013 yang dibandingkan dengan signifikan sebesar 0,05 . Karena nilai $p$-value $<$ signifikan $(0,013<0,05)$ dengan nilai beta sebesar positif 0,334 dan nilai t statistics sebesar 2,500 yang dibandingkan dengan t-tabel sebesar 2,006. Karena nilai t-statistics $>$ t-value $(2,500>2,006)$ maka dapat disimpulkan bahwa komitmen organisasional mampu memediasi secara signifikan pengaruh kepuasan kerja terhadap kinerja karyawan.

Uji peran mediasi komitmen organisasional pada pengaruh kepuasan kerja terhadap kinerja karyawan dapat dilakukan dengan memeriksa koefisien pengaruh langsung variabel bebas terhadap variabel terikat pada model dengan melibatkan variabel mediasi. Hasil pemeriksaan uji mediasi telah menunjukkan bahwa sesuai dengan kriteria pengaruh variabel bebas terhadap variabel mediasi $(0,000<0,05)$ adalah signifikan, pengaruh variabel mediasi terhadap varibel terikat $(0,008<0,05)$ adalah signifikan, pengaruh langsung variabel bebas terhadap variabel terikat pada model dengan melibatkan variabel mediasi $(0,000<0,05)$ adalah signifikan, maka dapat dikatakan sebagai partial mediation. Dengan demikian, komitmen organisasional sebagai partial mediation antara pengaruh kepuasan kerja terhadap kinerja karyawan, maka hipotesis 4, yang menyatakan bahwa komitmen organisasional mampu memediasi secara positif dan signifikan pengaruh Kepuasan kerja terhadap kinerja karyawan diterima.

Pengambilan kesimpulan dengan efek mediasi adalah mediasi partial. Ini dibuktikan dengan efek $\mathrm{C}$, D dan A signifikan, maka mediasi terbukti secara partial atau terjadi mediasi parsial pada model. Hipotesis $4\left(\mathrm{H}_{4}\right)$ yang menyatakan bahwa komitmen organisasional memediasi pengaruh kepuasan kerja terhadap kinerja karyawan diterima. Hal ini memiliki makna bahwa kepuasan kerja dapat memicu munculnya komitmen organisasional yang mampu memperkuat dampak terhadap peningkatan kinerja karyawan. 
Pengujian hipotesis pada pengaruh kepuasan kerja terhadap kinerja karyawan menunjukkan bahwa kepuasan kerja berpengaruh positif dan signifikan terhadap kinerja karyawan Krisna Oleh - Oleh Khas Bali I. Dilihat rata - rata nilai kepuasan kerja yaitu 3,64 yang berarti puas. Karyawan menyatakan mampu bekerjasama dengan sesama rekan kerja dengan baik, karyawan memiliki hubungan yang baik dengan rekan kerja, karyawan merasa puas dengan kesempatan yang diberikan untuk mengembangkan diri, karyawan merasa puas karena mendapatkan kesempatan untuk belajar atas pekerjaan yang diberikan. Hal ini berarti bahwa apabila kepuasan kerja semakin meningkat maka kinerja karyawan semakin meningkat pula.

Hasil penelitian ini sesuai dengan hipotesis satu $\left(\mathrm{H}_{1}\right)$ yang diajukan untuk mendukung penelitian yang dilakukan oleh Talasaz et al. (2014), Riyadi (2015), Anwar et al. (2015) yang menyatakan kepuasan kerja berpengaruh positif dan signifikan terhadap kinerja karyawan.

Pengujian hipotesis pada pengaruh kepuasan kerja terhadap komitmen organisasional menunjukkan bahwa kepuasan kerja berpengaruh positif dan signifikan terhadap komitmen organisasional karyawan Krisna Oleh - Oleh Khas Bali I. Dilihat rata - rata nilai kepuasan kerja yaitu 3,64 yang berarti puas. Karyawan menyatakan mampu bekerjasama dengan sesama rekan kerja dengan baik, karyawan memiliki hubungan yang baik dengan rekan kerja, karyawan merasa puas dengan kesempatan yang diberikan untuk mengembangkan diri, karyawan merasa puas karena mendapatkan kesempatan untuk belajar atas pekerjaan yang diberikan. Hal ini berarti bahwa apabila kepuasan kerja semakin meningkat maka komitmen organisasional semakin meningkat pula.

Hasil penelitian ini sesuai dengan hipotesis dua $\left(\mathrm{H}_{2}\right)$ yang diajukan untuk mendukung penelitian yang dilakukan oleh Rehman et al. (2013), Dwiki \& Riana (2018), Shah et al. (2014), Imam et al. (2014) yang menyatakan kepuasan kerja berpengaruh positif dan signifikan terhadap komitmen organisasional karyawan.

Pengujian hipotesis pada pengaruh komitmen organisasional terhadap kinerja karyawan menunjukkan bahwa komitmen organisasional berpengaruh positif dan signifikan terhadap kinerja karyawan Krisna Oleh - Oleh Khas Bali I. Dilihat rata rata nilai komitmen organisasional yaitu 3,64 yang berarti tinggi. Karyawan merasa terikat secara emosional dengan perusahaan, karyawan merasa bangga menjadi bagian dari perusahaan, karyawan menganggap bekerja pada perusahaan ini merupakan suatu kebutuhan sehingga karyawan akan tetap loyal terhadap perusahaan. Hal ini berarti bahwa apabila komitmen organisasional semakin meningkat maka kinerja karyawan semakin meningkat pula.

Hasil penelitian ini sesuai dengan hipotesis tiga $\left(\mathrm{H}_{3}\right)$ yang diajukan untuk mendukung penelitian yang dilakukan oleh Ghorbanpour et al. (2014), Akbar dkk. (2017), Damaryanti \& Dewi (2016), Asiedu et al. (2014) yang menyatakan komitmen organisasional berpengaruh positif dan signifikan terhadap kinerja karyawan.

Signifikansi hubungan tidak langsung antara kepuasan kerja terhadap kinerja karyawan melalui komitmen organisasional sebagai variabel mediasi. Karena nilai $p$-value $<$ signifikan $(0,013<0,05)$ dengan nilai beta sebesar positif 0,334 dan nilai $\mathrm{t}$ statistics sebesar 2,500 yang dibandingkan dengan t-tabel sebesar 2,006. Karena 
nilai t-statistics $>$ t-value $(2,500>2,006)$ maka dapat disimpulkan bahwa komitmen organisasional mampu memediasi secara signifikan pengaruh Kepuasan kerja terhadap kinerja karyawan Krisna Oleh - Oleh Khas Bali I.

Hasil penelitian ini sesuai dengan hipotesis empat $\left(\mathrm{H}_{4}\right)$ yang diajukan untuk mendukung penelitian yang dilakukan oleh Novita dkk. (2016), Wahyudi \& Sudibya (2016) yang menyatakan komitmen organisasional berpengaruh positif dan signifikan dalam memediasi pengaruh kepuasan kerja terhadap kinerja karyawan.

Implikasi hasil penelitian bertujuan untuk menekankan pada manfaat nyata dari hasil penelitian untuk meningkatkan kinerja karyawan Krisna Oleh - Oleh Khas Bali I dengan meningkatkan kepuasan kerja dan komitmen organisasional. Beberapa implikasi strategis hasil penelitian ini adalah sebagai berikut:

Pertama, responden menyetujui bahwa kepuasan kerja mampu meningkatkan kinerja karyawan. Salah satu indikator kepuasan kerja, yaitu kemampuan bekerjasama dengan baik saangat diperlukan untuk meningkatkan kinerja karyawan Krisna Oleh - Oleh Khas Bali I. Bila karyawan mampu bekerja sama dengan baik, maka rasa puas dalam bekerja akan tumbuh sehingga pekerjaan akan terasa lebih ringan dan cepat terselesaikan. Maka dari itu, penting bagi manajemen Krisna Oleh - Oleh Khas Bali I untuk memperhatikan kepuasan kerja karyawan.

Kedua, meningkatnya komitmen organisasional juga dapat meningkatkan kinerja karyawan Krisna Oleh - Oleh Khas Bali I. Pernyataan responden tentang "Saya merasa terikat secara emosional dengan perusahaan ini". Hal ini menunjukan bahwa karyawan memiliki rasa keterikatan terhadap tempat ia bekerja. Apabila karyawan merasa terikat secara emosional kepada perusahaan, maka karyawan tersebut akan loyal kepada perusahaan sehingga akan mempengaruhi kinerja karyawan tersebut untuk mencapai tujuan perusahaan.

Implikasi yang ketiga, pernyataan responden tentang "Saya menargetkan hasil yang harus dicapai dalam pekerjaan". Hal ini menunjukan karyawan sudah memiliki standar kerja pada dirinya. Karyawan yang menargetkan hasil dalam pekerjaannya menandakan kinerja karyawan yang baik dan tujuan perusahaan juga akan tercapai.

\section{SIMPULAN}

Berdasarkan hasil analisis penelitian dan hasil pembahasan pada bab sebelumnya maka simpulan dari penelitian ini adalah sebagai berikut Kepuasan kerja berpengaruh positif dan signifikan terhadap kinerja karyawan. Hal ini berarti apabila kepuasan kerja semakin meningkat maka kinerja karyawan semakin meningkat pula. Kepuasan kerja berpengaruh positif dan signifikan terhadap komitmen organisasional. Hal ini berarti apabila kepuasan kerja semakin meningkat maka komitmen organisasional semakin meningkat pula. Komitmen Organisasional berpengaruh positif dan signifikan terhadap Kinerja Karyawan. Hal ini berarti apabila jika Komitmen Organisasional semakin meningkat maka Kinerja Karyawan semakin meningkat. Komitmen organisasional berpengaruh signifikan dalam memediasi pengaruh kepuasan kerja terhadap kinerja karyawan. Hal ini berarti komitmen organisasional dapat memperkuat pengaruh Kepuasan kerja terhadap kinerja karyawan. 
Saran yang dapat diberikan berdasarkan kesimpulan yang didapat adalah sebagai berikut Dilihat dari rata - rata indikator pada variabel kinerja karyawan, nilai rata -rata terendah terdapat pada pernyataan "Rencana kerja saya berjalan optimal". Hal ini menunjukan bahwa rencana yang dimiliki karyawan tidak sepenuhnya terlaksana dengan baik. Sehingga ada baiknya pihak manajemen Krisna Oleh - Oleh Khas Bali I memberikan perhatian lebih terhadap karyawan guna meningkatkan kinerjanya seperti meningkatkan kualitas dan kuantitas pelatihan dan pengembangan SDM agar rencana kerja karyawan berjalan dengan baik sesuai dengan uraian tugas yang diberikan.

Dilihat dari rata - rata indikator pada variabel kepuasan kerja karyawan, nilai terendah terdapat pada pernyataan "Saya merasa puas dengan tunjangan yang diberikan perusahaan". Hal ini menunjukan bahwa perusahaan belum mampu memberikan kepuasan kepada karyawan dalam memberikan tunjangan. Sehingga ada baiknya pihak manajemen Krisna Oleh - Oleh Khas Bali I bisa meningkatkan kepuasan kerja karyawan dengan memberikan tunjangan yang lebih baik agar kinerja karyawan semakin meningkat. Dilihat dari rata - rata indikator pada variabel komitmen organisasional, nilai terendah terdapat pada pernyatan "Saya merasa rugi apabila keluar dari perusahaan ini,". Hal ini menunjukan bahwa karyawan akan mengalami kerugian jika memutuskan untuk keluar atau resign dari tempat bekerja. Sehingga pihak manajemen Krisna Oleh - Oleh Khas Bali I harus bisa mempertahankan karyawannya agar tetap bekerja dalam perusahaan ini dengan cara meningkatkan kepuasan kerja serta hubungan yang baik antara perusahaan dengan karyawannya.

Bagi peneliti selanjutnya diharapkan untuk mengkaji lebih banyak sumber maupun referensi yang terkait dengan variabel penelitian, serta mempertimbangkan variabel - variabel lain yang mempengaruhi kinerja karyawan

\section{REFERENSI}

Abdulwahab, S. B. S. (2016). The Relationship Between Job Satisfaction, Job Performance And Employee Engagement: An Explorative Study. Business Management and Economics Journal, 4(1), 1-8.

Akbar, A., Musadieq, M. Al, \& Mukzam, M. D. (2017). Pengaruh Komitmen Organisasional Terhadap Kinerja (Studi Pada Karyawan PT Pelindo Surabaya). Jurnal Administrasi Bisnis, 47(2), 1-10.

Andini, O. P., Sunuharyo, B. S., \& Utami, H. N. (2018). Pengaruh Kepuasan Kerja Terhadap Stres Kerja dan Turnover Intension Karyawan (Studi pada karyawan PT. Indolakto Factory Pandaan). Journal Administrasi Bisnis, 54(1), 1-12.

Anwar, B. ., Maupa, H., Ali, M., \& Ismail, M. (2015). The Effects of Work Stress and Compensation on the Employees Performance throught Motivation and Job Satisfaction at the Private Life Insurance Companies in Jakarta, Indonesia. Scientific Research Journal (SCIRJ), 3(9), 33-36.

Ardi, T. B., \& Sudarma, K. (2015). Pengaruh Perssepsi Dukungan Dan Keadilan 
Organisasi Terhadap Organizational Citizenship Behavior Dengan Komitmen Organisasional Sebagai Variabel Intervening. Management Analysis Journal, $4(2), 142-152$.

Asiedu, M., Sarfo, J. O., \& Adjei, D. (2014). Organisational Commitment And Citizenship Behaviour: Tools To Improve Employee Performance; An Internal Marketing Approach. European Scientific Journal, 10(4), 1857 - 788.

Damaryanti, A. A. I., \& Dewi, A. A. S. (2016). Pengaruh Kecerdasan Emosional, Komitmen Organisasi, Dan Organizational Citizenship Behavior Terhadap Kinerja Pegawai Feb. E-Jurnal Manajemen Unud, 5(2), 790-820.

Damayanthi, A. A. S. S., \& Sintaasih, D. K. (2016). Pengaruh Keselamatan Dan Kesehatan Kerja Terhadap Komitmen Organisasional Dan Kinerja Karyawan. E-Jurnal Manajemen Udayana, 14(2), 1-20.

Dwiki, I. M., \& Riana, I. G. (2018). Peran Kepuasan Kerja Dalam Memediasi Pengaruh Servant Leadership Terhadap Komitmen Organisasi. E-Jurnal Manajemen Unud, 7(9), 4747-4773.

Fadilah, A. N., Hakim, A., \& Siswidiyanto. (2014). Pengaruh Penempatan Pegawai Terhadap Kinerja (Studi pada Pegawai Sekretariat Daerah Kabupaten Gresik). Jurnal Administrasi Publik (JAP), 1(5), 847-852.

Ghorbanpour, Z., Dehnavi, H. D., \& Heyrani, F. (2014). Investigating the Effect of Organization Commitment on Performance of Auditors in the Community of Certified Accountants. Interdisciplinary Journal Of Contemporary Research In Business, 5(10), 199-209.

Imam, A., Raza, A., \& Lecturer, A. M. (2014). Impact Of Job Satisfaction On Organizational Commitment In Bank Sector Employees Of Pakistan. Science Journal of Business and Management, 26(1), 419-423.

Indrawan, D. C., \& Dewi, A. A. S. K. (2014). Pengaruh Kompensasi, Kepemimpinan, Dan Lingkungan Kerja Fisik Terhadap Kepuasan Kerja Karyawan PT Cargo Asas International, Denpasar. E-Jurnal Manajemen Universitas Udayana, 3(6), 1767-1779.

Koopmans, L., Bernaards, C. M., Hildebrandt, V. H., Vet, H. C. W. De, \& Beek, A. Van Der. (2014). Construct Validity Of The Individual Work Performance Questionnarie. Journal Of Occupational Dan Environmental Medicine, 56(3), 331-337.

Kusuma, B. H., \& Lina. (2018). Pengaruh Kepuasan Karyawan Terhadap Kinerja Karyawan Dengan Komitmen Organisasi Sebagai Variabel Intervening (Survai Pada Perguruan Tinggi Swasta Di Wilayah Jakarta Barat). Jurnal 
Manajemen Maranatha, 17(2), 127-134.

Novita, S., Bambang, S., \& Ruhana, I. (2016). Pengaruh Kepuasan Kerja Dan Komitmen Organisasional Terhadap Kinerja Karyawan (Studi Pada Pt. Telekomunikasi Indonesia, Tbk Witel Jatim Selatan, Malang). Jurnal Administrasi Bisnis, 34(1), 1-20.

Puangyoykeaw, K., \& Nishide, Y. (2015). Organizational Commitment and Turnover Intention in Low-Skilled Immigrant Worker in Thailand: An Empirical Assessment of Need Satisfaction, Job Satisfaction and Overall Life Satisfaction Factors. International Journal of Business and Management, 10(5), 98-112.

Rehman, K., Rehman, Z.-U., Saif, N., Khan, A. S., Nawaz, A., \& Rehman, S. U. (2013). Impact of Job Satisfaction on Organizational Commitment: A Theoritical Model for Academicians in HEI of Developing Countries like Pakistan. Internasional Journal of Business and Economic, 1(1), 1-10.

Riyadi, S. (2015). Effect of Work Motivation, Work Stress and Job Satisfaction on Teacher Performance at Senior High School (SMA) Throughout The State Central Tapanuli, Sumatera. IOSR Journal Of Humanities And Social Science, 20(2), 52-57.

Rizwan, M. (2014). Preceding To Employee Satisfaction And Turnover Intention. International Journal Of Human Resource Studies, 4(3), 87-106.

Rosita, T., \& Yuniati, T. (2016). Pengaruh Kepuasan Kerja Terhadap Kinerja Karyawan Dengan Komitmen Organisasional Sebagai Variabel Intervening. Jurnal Ilmu Dan Riset Manajemen, 5(1), 1-20.

Shah, F. T., Idrees, F., Imam, A., Khan, T. A., \& Mariyam, A. (2014). Impact of Job Satisfaction on Organizational Commitment in IT Sector Employees of Pakistan. Journal of Applied Environmental and Biological Sciences, 4(8), 190-197.

Shurbagi, A. (2014). The Relationship between Transfornational Leadership Style Job Satisfaction and The Effect of Organizational Commitment. International Business Research, 7(11), 126-138.

Talasaz, Z. H., Saadoldin, S. N., \& Shakeri, M. T. (2014). The Relationship between Job Satisfaction and Job Performance Among Midwives Working in Healthcare Centers of Mashhad, Iran. Journal of Midwifery and Reproductive Health, 2(3), 157-164.

Than, V. D., Pham, C. H., \& Pham, L. (2016). Job Stress, Involvement, Satisfaction, and Performance of Employees In Garment 10 Coorporation in Vietnam. 
I Ketut Edy Mardyana, Peran Komitmen Organisasional...

International Journal Of Financial Research, 7(3), 96-109.

Triwahyuni, R., \& Ekowati, V. M. (2017). The Effect Of Employees Satisfaction On Employee Performance Throught Organizational Commitment. Management And Economic Journal, 1(1), 1-20.

Wahyudi, N. K. S., \& Sudibya, I. G. A. (2016). Pengaruh Kepuasan Kerja Dan Komitmen Organisasional Pada Kinerja Karyawan Di Natya Hotel, Kuta Bali. E-Jurnal Manajemen Unud, 5(2), 870-897.

Widyastuti, F. (2015). Pengaruh Penempatan Pegawai Terhadap Kinerja Pegawai Di PDAM Tirta Kahuripan Kabupaten Bogor. Jurnal Prosiding Spesial, 1(1), $120-125$. 